\title{
Detoxified Physic Nut Meal (Jatropha Curcas L.) As Ingredient for Animal Feed
}

\author{
B. Berenchtein ${ }^{1}$; Abdalla. A.L. ${ }^{2}$; A.A.S.Morsy ${ }^{2}$; A.L. Abdalla Filho ${ }^{2}$; \\ P.B. Godoy ${ }^{2}$; P.P. Santos ${ }^{2}$; J.D.F. Gomes ${ }^{3}$; L.A. Castilho' ${ }^{2}$ T.P. Paim ${ }^{2}$ \\ IAnimal Science College. Laboratory of Animal Nutrition - Social Sciences, Education and Animal Science \\ Institute - Federal University of Amazonas. Parintins-Macurany Road. 1805. CEP 69152-805. Parintins - AM. \\ Brazil \\ 2Laboratory of Animal Nutrition - Centre of Nuclear Energy in Agriculture - University of São Paulo. Av. \\ Centenário. 303. CP 96. CEP 13400-970. Piracicaba - SP.Brazil \\ 3Animal Science Department - College of Animal Science and Food Engineering - University of São Paulo. Av. \\ Duque de Caxias Norte. 225. CEP 13635-900. Pirassununga-SP.Brazil
}

\begin{abstract}
This study aims to evaluate the efficiency of physic nut meal detoxification and the useful of this meal in Wistar rats (Rattus norvegicus) feed. Twenty-four animals, 21-25 days old and initial mean body weight $69.9 \mathrm{~g} \pm 5.40 \mathrm{~g}$ were used. The animals received three diets: Control (base ration,. ration with $5 \%$ of detoxified physic nut meal and ration with $10 \%$ of the same meal. A no-protein diet was included aiming to correct the digestibility by protein consumption and wasted. This diet was distributed in six random blocs according to animal's initial live body weight. Total faeces excreted in 24 hours by rats were collected, dried at $60{ }^{\circ} \mathrm{C}$, grounded and weighted to digestibility calculation. After 28 experimental days, the animals were submitted to $12 \mathrm{~h}$-fasting and were anesthetized with halothane saturated chamber. Thereafter, the internal organs (liver, heart, and kidney, intestine) were weighted and blood samples were taken. The intestines were dissected and separated small intestine and intestine, which it were used to measurement of intestine length. The detoxified physic nut $(D P N)$ had a negative effect $(P>0.05)$ in animal growth and also in digestibility of diets. The organs weights did not differ between treatments in analysis of variance. However, the regression analysis identified a negative quadratic effect of DPN in liver weight. Moreover, DPN had a positive linear effect in intestine weights. The analysis of variance did not detect any effect of treatments in blood parameters, as well as in hepatic transaminazes enzimes. On the other hand, the regression showed that DPN had a negative quadratic effect in aspartate aminotransferase level. Therefore, the physic nut meal can be considered a promissory protein source. Further studies must be realized to evaluate the physic nut meal in diets of others species, as well as the effect and content of other bioactive molecules.
\end{abstract}

Keywords - Blood parameters, Co-product, Digestibility, Performance, Wistar rats

\section{INTRODUCTION}

The energy is an actual worldwide issue, due to it be an essential factor to social and economic development. Nevertheless, $90 \%$ of total energy consumption comes from fossil sources, which are exhaustible. Hence researches to development of alternative energy sources as biodiesel are need aiming to amplify and diversify the energy supply, always looking for environmental sustainability [1].

The physic nut is considered a promissory legume to biofuel production due to high oil level ( $25 \mathrm{a}$ $40 \%$ ) being higher than other legumes commonly used [2]. It is a shrub of euphorbia family native from South America and had been successfully explored in Central America, India and Africa.

The biodiesel production generate some subproducts which must be evaluated carefully because can be a determinant factor to economic viability to production of this biofuel. The biodiesel production from physic nut produces glycerin, lecithin, cake and meal as co-products. However, studies about the use of these products aiming to increase the viability of productive chain are scarce [3].

The physic nut meals have a great potential to utilization in animal feed due to high protein level. However, this product have bioactive compounds (phytate and trypsin inibitors) and toxic compounds (curcina and phorbol esters [4] [5], which may cause diarrhea, dyspnea and dehydration in animals fed with it. Therefore, the physic nut meal can be utilized in animal feed since adequate treatment be realized to reduction or elimination of these anti-nutritional factors [3], which is similar, for example, with the processes make to cottonseed meal and sunflower meal utilization in animal feed [6].

In this sense, this study aims to evaluate the use of detoxified physic nut in feed of Wistar rats. The intention was verify the efficiency of detoxification process in a non-ruminant animal model, aiming to extrapolate these results to further tests with different animal species. 


\section{Materials AND Methods}

Twenty-four 21-25 days old albino rats (Rattus norvegicus) from Wistar linage, mean initial body weight equal to $69.9 \mathrm{~g} \pm 5.40$, were used. These animals were divided in three is nutritious diets: basal ration described by [7]; basal ration with 5\% of detoxified physic nut meal; and ration with $20 \%$ of detoxified physic nut meal. The physic nut meal used was obtained from legume overwhelming to biodiesel production. After, the detoxification was carried in industrial condition.

A no-protein diet was included aiming to correct consumed and eliminated protein to digestibility calculation (Table 1). The diets were distributed in six blocks in a randomly blocks design according to animal initial body weight. The animals were allocated in individual cages, receiving the diets during 28 days with ad libitum water supply and ration.

Tohlo 1 Derrontace somnocition salmilated or analiced valuac of hacal diate

\begin{tabular}{|c|c|c|c|c|}
\hline \multirow{2}{*}{ Ingredient } & \multicolumn{3}{|c|}{ DPNM in diet. $\%$} & \multirow{2}{*}{ No-protein } \\
\hline & 0 & 5 & 10 & \\
\hline Casein ( $\geq 85 \%$ of protein) & 20.0 & 16.35 & 12.68 & 0 \\
\hline DPNM in diet & 0 & 5.0 & 10.0 & 0 \\
\hline Com starch & 39.75 & 38.41 & 37.07 & 59.75 \\
\hline Dextrinized com starch & 13.20 & 13.20 & 13.2 & 13.2 \\
\hline Soybean oil & 7.0 & 7.0 & 7.0 & 7.0 \\
\hline Sucrose & 10.0 & 10.0 & 10.0 & 10.0 \\
\hline Microcristalized cellulose & 5.0 & 5.0 & 5.0 & 5.0 \\
\hline Mineral mixture (AIN-93 G-MX) & 3.5 & 3.5 & 3.5 & 3.5 \\
\hline Vitamin mixture (AIN-93G-VX) ${ }^{2}$ & 1.0 & 1.0 & 1.0 & 1.0 \\
\hline L-cistine & 0.3 & 0.3 & 0.3 & 0.3 \\
\hline Bitartarato de colina & 0.25 & 0.25 & 0.25 & 0.25 \\
\hline Tert Butylhidroquinona (TBHq) & 0.0014 & 0.0014 & 0.0014 & 0.0014 \\
\hline \multicolumn{5}{|l|}{ Nutritional composition ${ }^{3}$ : } \\
\hline Dry Matter $\left(100^{\circ} \mathrm{C}\right) . \%$ & 97.3 & 93.0 & 92.9 & 97.3 \\
\hline Ash $\%$ & 2.6 & 3.0 & 3.8 & 1.7 \\
\hline Crude protein $\%$ & 21.3 & 19.7 & 20.9 & 2.0 \\
\hline Ether extract $\%$ & 6.0 & 7.0 & 7.6 & 7.9 \\
\hline Crude fiber $\%$ & 3.4 & 4.1 & 4.5 & 2.9 \\
\hline Phorbol esters (mg g) & 0 & 0.09 & 0.11 & 0 \\
\hline
\end{tabular}

${ }^{1}$ Quantity per kg of diet: Anhydrous Calcium Carbonate - $357 \mathrm{~g}$, monobasic potassium phosphate - $196 \mathrm{~g}$, Potassium Citrate - $70.78 \mathrm{~g}$, Sodium Chloride - $74.00 \mathrm{~g}$, potassium sulfate - $46.60 \mathrm{~g}$, magnesium oxide - $24 \mathrm{~g}$; Iron Citrate - $6.6 \mathrm{~g}$; Zinc carbonate $-1.65 \mathrm{~g}$; Manganese carbonate $-0.63 \mathrm{~g}$; Copper $^{+2}$ carbonate $-0.30 \mathrm{~g}$, Potassium iodate - $0.01 \mathrm{~g}$, Sodium selenate - $0.01025 \mathrm{~g}$; Paramolibdato of Ammonia - $0.00795 \mathrm{~g}$, Beta Sodium silicate - 1:45 g, Potassium Sulfate Chromium - $0275 \mathrm{~g}$; Lithium chloride - $0.0174 \mathrm{~g}$, boric acid - $0.0815 \mathrm{~g}$, Sodium Fluoride - $0.0635 \mathrm{~g}$; Nickel carbonate - $0.0318 \mathrm{~g}$, Ammonium vanadate - 0.0066g; Sucrose - 221.0260 g. ${ }^{2}$ Units per kg of diet: Nicotinic acid - $3.00 \mathrm{~g}$, Calcium Pantothenate - $1.60 \mathrm{~g}$; Pyridoxine - $0.70 \mathrm{~g}$; Thiamin $0.60 \mathrm{~g}$, Riboflavin - $0.60 \mathrm{~g}$; Folic Acid - $0.20 \mathrm{~g}$, Biotin - $0.02 \mathrm{~g}$, Vitamin $\mathrm{B}_{12}-2.50 \mathrm{~g}$, vit. E - $15.0 \mathrm{~g}$, vit. A - 0.80 g, vit. $\mathrm{D}_{3}-0.25 \mathrm{~g}$, vit. K - $0.075 \mathrm{~g}$, Sucrose - $974655 \mathrm{~g}$.

The animal live weight and ration intake were registered three times per week, after the feed conversion was obtained dividing the feed intake by body weight gain. The mortality was measured daily. The feces were collected, dried at $60^{\circ} \mathrm{C}$ in stove, grounded and weighted. The nitrogen levels in feces were measured daily in a pool of feces samples, aiming the 24-h digestibility calculation. 
After 28 experimental days, the animals suffer a $12 \mathrm{~h}$ fasting period and were anesthetized in halothane saturated chamber. After, the abdominal cavity was opened and the internal organs (liver, heart, kidneys and intestine) were retired and weighted. The relative weight of each organ by $100 \mathrm{~g}$ of live weight was calculate by the total organ weight multiplicate by 100 and divided by animal live weight.

The intestine was dissected and separated in large intestine (LI) and small intestine (SI), being measured the SI length. Afterward, it was collected blood samples to analyze erythrocytes count $\left(\mathrm{x} 106 / \mathrm{mm}^{3}\right)$, hemoglobin $(\mathrm{g} / \mathrm{dl})$, packed cell volume $(\%)$, mean packed cell volume (MPCV), mean concentration of packed hemoglobin (MCPH) $(\%)$, total plasma $(\mathrm{g} / \mathrm{dl})$, leucocytes $\left(\mathrm{x} 103 / \mathrm{mm}^{3}\right)$ and liver transaminase enzymes, alanine aminotransferase (ALT) (UI/l) and aspartate aminotransferase (AST) (UI/l).

The abdominal, thoracic and head cavities were opened and lyophilized until total drying. The nitrogen in feces and carcass were determined by technique described by [8]. To digestibility determination (\%). it was utilized the follow equation:

$\mathrm{D}=(\mathrm{P}$ consumed $-\mathrm{P}$ excreted $-\mathrm{P}$ excreted by no-protein group $) / \mathrm{P}$ consumed $* 100$. being $\mathrm{P}=$ protein.

The methodology from [9] was used to protein efficiency (PE) determination. following the equation:

$\mathrm{PE}=$ Body weight gain $(\mathrm{g}) /$ Consumed protein $(\mathrm{g})$

The random blocks experimental design was used with three treatments and six repetitions by treatment. The data was analyzed by SAS LAB to verify the data adjustment to linear model. Afterward, it was realized an analysis of variance using the GLM procedure of SAS®9.1. Beyond it, was realized the decomposition of degrees of freedom decomposition in individual compounds (linear and quadratic) of regression through orthogonal polynomials. Then it was tested a specific contrast with practical interest $(\mathrm{C} 1=$ control treatment $\mathrm{x}$ means of treatments 5 and $10 \%$ of detoxified physic nut meal).

\section{RESULTS AND DISCUSSION}

The analyses of variance show that the detoxified physic nut meal (DPNM) did not influence the animal growth (Table 3). After the decomposition of the degrees of freedom, the level of DPNM did not show effect on animal growth. The contrast analysis comparing the control diet to 5 and $10 \%$ DPNM diets showed no difference $(\mathrm{P}>0.05)$ between the treatments.

Table 3. Average initial body weight (IBW), final body weight (FBW), daily feed intake (DFI), average daily gain (ADG), feed conversion (FC), digestibility (D) and protein efficiency ratio (PER) of Wistar rats fed with levels of detoxified physic nut meal in the diet.

\begin{tabular}{|c|c|c|c|c|c|c|c|c|}
\hline \multirow{2}{*}{ Variables } & \multicolumn{3}{|c|}{ DPNM in diet $\%$} & \multirow{2}{*}{$\mathrm{P}$} & \multicolumn{2}{|c|}{ Regression $^{1}$} & \multirow{2}{*}{$\frac{\text { Contrast }^{2}}{\mathrm{C} 1}$} & \multirow{2}{*}{$\begin{array}{l}\mathrm{CV}^{3} \\
(\%)\end{array}$} \\
\hline & 0 & 5 & 10 & & $\mathrm{~L}$ & $\mathrm{Q}$ & & \\
\hline IBW (g) & 69.35 & 71.41 & 68.9 & .. & .. &.. & .. & .. \\
\hline FBW (g) & $\begin{array}{c}214.1 \\
8\end{array}$ & $\begin{array}{c}217.0 \\
2\end{array}$ & 217.35 & $\mathrm{~ns}$ & ns & ns & ns & 3.35 \\
\hline DFI (g/dia) & 16.02 & 15.58 & 15.95 & $\mathrm{~ns}$ & ns & ns & ns & 4.39 \\
\hline ADG (g/dia) & 5.36 & 5.39 & 5.50 & $\mathrm{~ns}$ & ns & ns & ns & 5.27 \\
\hline $\mathrm{FC}$ & 2.99 & 2.89 & 2.91 & $\mathrm{~ns}$ & $\mathrm{~ns}$ & $\mathrm{~ns}$ & $\mathrm{~ns}$ & 3.55 \\
\hline $\mathrm{D}(\%)$ & 81.84 & 74.00 & $\begin{array}{c}72.0 \\
0\end{array}$ & $<0.001$ & $<0.001$ & ns & $<0.001$ & 1.40 \\
\hline PER & 1.57 & 1.81 & 1.60 & $\mathrm{~ns}$ & $\mathrm{~ns}$ & $\mathrm{~ns}$ & $\mathrm{~ns}$ & 8.93 \\
\hline Variable & \multicolumn{7}{|c|}{ Regression equation } & $\mathrm{R}^{2}$ \\
\hline $\mathrm{D}(\%)$ & \multicolumn{7}{|c|}{$y=-0.9746 x+80.852$} & 0.89 \\
\hline
\end{tabular}

${ }^{1}$ Regression: $\mathrm{L}=$ linear effect; $\mathrm{Q}=$ quadratic effect

${ }^{2}$ Contraste: $\mathrm{C} 1=0 \% \mathrm{x}$ average of 5 and $10 \%$

${ }^{3}$ Coefficient of variation

ns $=$ not significant

These results differ from which was found by [10] and [11]. These authors found a reduction in daily ration intake and, consequently, a reduction in mean life weight and daily weight gain of animals. Probably, this reduction in feed intake is due to smell, taste and texture, or yet some intolerance to phorbol esters [12]. [11] proved that the phorbol esters in rat diets is able to induce weight loss. The concentration of $0.02 \mathrm{mg} / \mathrm{g}$ of phorbol esters in diet resulted in significant adverse effects in intake and growth rate of rats.

However, the processed physic nut meal showed a higher value to weight gain and protein efficiency in the group of rats fed with processed physic nut meal [12]. These authors evaluated the atoxic physic nut meal from varieties originated in Vera Cruz. Mexico, processed in four temperatures. 
In this study, the DPNM added in diet led to a significant reduction in digestibility $(\mathrm{P}<0.05)$. It was observed a linear reduction in digestibility due to addiction of 5 and $10 \%$ of DPNM in diet. Nevertheless, the DPNM in diets did not influence the protein efficiency rate (PER). These results differed from which was found by [10] that related a significant reduction in PER of animals that received detoxified physic nut meal in diet.

The relative weight of liver, kidneys, heart, large intestine and small intestine length of animals receiving different treatments did not differ significantly ( $>>0.05)$ (Table 4). However, the DPNM level in diet had a quadratic effect in the liver relative weight. The liver weight can increase with the increment in crude protein consumption [13], because this organs is responsible for aminoacids degradation and nitrogen metabolism [14].

Table 4. Average relative weight of internal organs (liver. heart. kidney and intestine) and the length of small intestine according to the level of inclusion of detoxified physic nut meal (DPNM) in diet.

\begin{tabular}{|c|c|c|c|c|c|c|c|c|}
\hline \multirow{2}{*}{ Variables } & \multicolumn{3}{|c|}{ DPNM in diet (\%) } & \multirow{2}{*}{$\mathrm{P}$} & \multicolumn{2}{|c|}{ Regression $^{5}$} & \multirow{2}{*}{$\frac{\text { Contrast }^{6}}{\mathrm{C} 1}$} & \multirow{2}{*}{$\begin{array}{c}\text { CV } \\
7 \\
(\%)\end{array}$} \\
\hline & 0 & 5 & 10 & & $\mathrm{~L}$ & $\mathrm{Q}$ & & \\
\hline Liver (\%) & 3.30 & 3.86 & 3.60 & ns & ns & $<0.0$ & $<0.05$ & 7.27 \\
\hline Kidney (\%) & 1.02 & 0.92 & 0.99 & $\mathrm{~ns}$ & $\mathrm{~ns}$ & $\mathrm{~ns}$ & 0.15 & 9.59 \\
\hline Heart (\%) & 0.48 & 0.41 & 0.45 & $\mathrm{~ns}$ & ns & ns & 0.42 & 22.05 \\
\hline Intestine $^{1}(\%)$ & 3.07 & 3.59 & 3.76 & $<0.05$ & $<0.05$ & ns & $<0.05$ & 12.72 \\
\hline $\mathrm{SI}^{2}(\%)$ & 2.41 & 2.65 & 2.90 & $<0.05$ & $<0.001$ & $\mathrm{~ns}$ & $<0.05$ & 7.39 \\
\hline $\mathrm{LI}^{3}(\%)$ & 0.66 & 0.93 & 0.85 & $\mathrm{~ns}$ & ns & ns & 0.21 & 46.8 \\
\hline $\mathrm{LSI}^{4}(\mathrm{~m})$ & 1.18 & 1.12 & 1.15 & $\mathrm{~ns}$ & $\mathrm{~ns}$ & ns & 0.20 & 5.08 \\
\hline Variables & \multicolumn{7}{|c|}{ Regression equation } & $\mathrm{R}^{2}$ \\
\hline Liver $(\%)$ & \multicolumn{7}{|c|}{$y=-0.0164 x^{2}+0.1933 x+3.3008$} & 0.99 \\
\hline Intestine $^{1}(\%)$ & \multicolumn{7}{|c|}{$y=0.0693 x+3.1282$} & 0.93 \\
\hline $\mathrm{SI}^{2}(\%)$ & \multicolumn{7}{|c|}{$y=0.0488 x+2.4097$} & 0.99 \\
\hline
\end{tabular}

${ }^{1}$ Small and Large intestines

${ }^{2}$ Small intestine

${ }^{3}$ Large intestine

${ }^{4}$ Lenght of small intestine

${ }^{5}$ Regression: $\mathrm{L}=$ linear effect; $\mathrm{Q}=$ quadratic effect

${ }^{6}$ Contrast: $\mathrm{C} 1=0 \% \mathrm{x}$ average of 5 and $10 \%$ of DPNM

${ }^{7}$ Coefficient of variation

$\mathrm{ns}=$ not significant

The DPNM level in diet had a positive linear effect in small intestine and in overall intestine relative weight (small and large intestine). The specific contrast $0 \%$ versus average of 5\% and 10\% of DPNM in diet also detected significant difference.

Different results were found by [11] that evaluating different methodologies to physic nut detoxification did not observe significant effect of physic nut meal in relation to control treatment (casein) to relative liver weight. These authors however observed an increase in the relative kidney weight, which, according to authors, was provoked by an essential aminoacids deficiency.

[15], testing the toxicity of physic nut oil in rats, mice and rabbits, observed diarrhea, ocular hemorrhage and gastric and intestine inflammation. These authors suggested that the toxic effects of oil are related with the phorbol esters.

The analyses of variance did not detect effect of detoxified physic nut meal addition in blood variables, as well in hepatic transaminases enzymes of animals (Table 5). The specific contrast $0 \%$ versus average of 5\% and $10 \%$ of DPNM in diet did not demonstrate difference to these same variables. On the other hand, the DPNM level in diet demonstrated quadratic effect in aspartate aminotransferase (AST) activity. 
Table 5. Blood hematological parameters and liver transaminase enzymes of Wistar rats fed with levels of detoxified physic nut meal.

\begin{tabular}{|c|c|c|c|c|c|c|}
\hline \multirow{2}{*}{ Variable } & \multicolumn{3}{|c|}{ DPNM in $\operatorname{diet}(\%)$} & \multicolumn{2}{|c|}{ Regressão $^{5}$} & \multirow{2}{*}{$\mathrm{CV}^{6}(\%)$} \\
\hline & 0 & 5 & 10 & $\mathrm{~L}$ & $\mathrm{Q}$ & \\
\hline Eritrocites $\left(\mathrm{x} 10^{6} / \mathrm{mm}^{3}\right)$ & 6.06 & 6.81 & 6.19 & $\mathrm{~ns}$ & $\mathrm{~ns}$ & 18.74 \\
\hline Hemoglobine (g/dL) & 12.94 & 13.85 & 12.70 & $\mathrm{~ns}$ & $\mathrm{~ns}$ & 15.66 \\
\hline Packed cell volume (\%) & 39.80 & 41.17 & 38.83 & ns & ns & 23.49 \\
\hline $\mathrm{PCM}^{1}(\mathrm{fl})$ & 66.06 & 59.95 & 62.13 & $\mathrm{~ns}$ & $\mathrm{~ns}$ & 9.52 \\
\hline $\operatorname{HPCMC}^{2}(\%)$ & 32.72 & 34.63 & 33.27 & ns & ns & 14.71 \\
\hline Total Protein (g/dL) & 6.56 & 6.37 & 6.33 & ns & $\mathrm{ns}$ & 3.68 \\
\hline Leucocites $\left(\mathrm{x} 10^{3} / \mathrm{mm}^{3}\right)$ & 7.01 & 7.88 & 6.58 & $\mathrm{~ns}$ & $\mathrm{~ns}$ & 32.76 \\
\hline $\mathrm{ALT}^{3}(\mathrm{UI} / \mathrm{L})$ & 18.90 & 17.75 & 20.42 & $\mathrm{~ns}$ & $\mathrm{~ns}$ & 22.51 \\
\hline $\mathrm{AST}^{4}(\mathrm{UI} / \mathrm{L})$ & 139.50 & 107.83 & 141.33 & ns & $<0.05$ & 21.74 \\
\hline Variable & \multicolumn{5}{|c|}{ Regression equation } & $\mathrm{R}^{2}$ \\
\hline $\mathrm{AST}^{4}(\mathrm{UI} / \mathrm{L})$ & \multicolumn{5}{|c|}{$y=1.3033 x^{2}-12.85 x+139.5$} & 0.99 \\
\hline $\begin{array}{l}\text { cked Cell mean volume } \\
\text { moglobine packed cell me } \\
\text { anine aminotransferase } \\
\text { partate aminotransferase } \\
\text { gression: } L=\text { linear effect; } \\
\text { efficient of variation } \\
\text { not significant }\end{array}$ & oncentrati & & & & & \\
\hline
\end{tabular}

In other animal species, [16] observed severe alterations in blood parameters in pigs due to addition of DPNM in diet, justified by the high toxicity of phorbol esters in physic nut. [17] fed calves with physic nut seeds in different doses during 14 days and observed deaths and an increase in aspartate aminotransferase activity, ammonia and potassium. These authors also observed a decrease in total protein and serum calcium. Moreover, in sheep and goat, [18] and [19] related occurrence of diarrhea, reduced consumption of water, dehydration and inappetence. Broilers fed with physic nut seeds during four weeks demonstrated severe intoxication due to growth reduction, lesions in liver and kidney and hemorrhagic lesions [20]

In recent study, [21] concluded that physic nut meal (without detoxification) in diet of fingerlings of Nile tilapia provoke deaths, therefore this product must not be used in feed of this fishes.

\section{CONCLUSION}

The detoxified physic nut meal is a promissory protein source for animal nutrition. Further research must be realized to evaluate detoxified physic nut meal in diet of different animal species. as well as the toxic effects in animal tissues. For this, it is very important to determine others bioactive compounds present in this product.

\section{Acknowledgements}

To FAPESP due to scholarship to first author. LABORE due to meals detoxification. Srs. Joaquim Everaldo dos Santos and Antonio Roberto de Godoi due to the help in experiment conduction.

\section{REFERENCES}

[1] Sousa. G.S.. Pires. M.M.. Alves. J.M.. 2006. Análise da potencialidade da produção de biodiesel a partir de óleos vegetais e gorduras residuais. In: XI SEMINÁRIO DE INICIAÇÃO CIENTÍFICA DA UESC. Santa Cruz. Anais...Santa Cruz. 477-478.

[2] Arruda. F.P.. Beltrão. N.E.M.. Andrade. A.P.. Pereira. W.E.. Severino. L.S.. 2004. Cultivo de pinhão-manso (Jatropha curcas L.) como alternativa para o Semi-Árido nordestino. Revista Brasileira de Oleaginosas e Fibrosas, v. 8. 789-799.

[3] Neiva Junior. A.P.. Van Cleef. E.H.C.B.. Pardo. R.M.P.. Silva Filho. J.C.. Castro Neto. P.. Fraga. A.C.. 2007. Subprodutos agroindustriais do biodiesel na alimentação de ruminantes. In: II CONGRESSO DA REDE BRASILEIRA DE TECNOLOGIA DE BIODIESEL. Brasília. Anais... Brasília: 2007. 6p.

[4] Makkar. H.P.S.. Becker. K.. Sporer. F.. 1997. Studies on nutritive potential and toxic constituents of different provenances of Jatropha curcas. Journal of Agriculture and Food Chemistry. Washington. v. 45. 3152-3157.

[5] Martinez-Herrera. J.. Siddhuraju. P.. Francis. G.. 2006. Chemical composition, toxic/antimetabolic constituents, and effects of different treatments on their levels, in four provances of Jatropha curcas L. from Mexico, Food Chemistry, Whiteknights, v. 96. 8089.

[6] El-Sayed. A.M.. 1999. Alternative dietary protein sources for farmed tilapia Oreochromis spp. Aquaculture. v. 179. 149-168. 
[7] Reeves. P.G.. Nielsen. F.H.. Fahey. G.C.. 1993. Ain-93 purified diets for laboratory rodents- final report of the American Institute of Nutrition ad hoc writing committee on the reformulation of the Ain- 76 a rodent diet. Journal of Nutrition. Bethesda. 23.11. 1939- 1951.

[8] Association Of Official Analytical Chemists. Official methods of analysis. 15. ed. Arlington: AOAC International. 1999. v.1.

[9] Osborne. T.B.. Mendel. L.B.. Ferry. E.L.. 1919. A method of expressing numerically the growth - promoting value of proteins. Journal of Biology and Chemistry. Baltimore. v. 37. 223-229.

[10] Aregheore, E.M.. Becker. K.. Makkar. H.P.S.. 2003. Detoxification of a toxic variety of Jatropha curcas using heat and chemical treatments, and preliminary nutritional evaluation with rats. South Pacific Journal Natural Science. v. 21. 50-56.

[11] Rakshit, K.D.. Darukeshwara. J.. Rathina. R.K.. Narasimhamurthy. P.. Saibaba; Bhagya. P.. 2008. Toxicity studies of detoxified Jatropha meal (Jatropha curcas) in rats. Food and Chemistry Toxic. 46. p. 3621-3625.

[12] Makkar. H.P.S.. Becker. K.. 1999. Plant toxins and detoxification methods to improve feed quality of tropical seeds - Review. Asian-Australian Journal of Animal Science. Seoul. 12. 467-480.

[13] Bikker. P.. 1994. Partitioning of dietary nitrogen between body components and waste in young growing pigs. Netherland Journal of Agricultural Science. v. 42. 37-45.

[14] Chen. H.Y.. 1999. The effect of excess protein on growth performance and protein metabolism of finishing barrows and gilts. Journal of Animal Science. v. 77. 3238-3247.

[15] Gandhi. V.M.. Cherian. K.M.. Mulky. M.J.. 1995. Toxicological Studies on Ratanjyot Oil. Food and Chemistry Toxic. 33. 39-42.

[16] Chivandi. E.. Erlwanger. K.H.. Makuza. S.M.. Read. J.S.. Mtimuni. J.P.. 2006. Effects of dietary Jatropha curcas meal on Percent Packed Cell Volume. Serum Glucose. Cholesterol and Triglyceride concentration and Alpha-Amylase activity of weaned fattening pigs. Research Journal of Animal and Veterinary Science. v. 1. 18-24.

[17] Ahmed. O.M.M.. Adam. S.E.I.. 1979a. Effects of Jatropha curcas on calves. Veterinary Pathology. V. 16. 476-482.

[18] Adam. S.E.I.. Magzoub. M.. 1975. Toxicity of Jatropha curcas for goats. Toxicology. 4. 3. 347-54.

[19] Ahmed. O.M.M.. Adam. S.E.I.. 1979b. Toxicity of Jatropha curcas in sheep and goats. Research Veterinary Science. v. $27.89-96$.

[20] El Badwi. S.M.A.. Adam. S.E.I.. 1992. Toxic effects of low levels of dietary Jatropha curcas seed on Brown Hisex chicks. Veterinary and Human Toxicology. 34. 2. 112-115.

[21] Fernandes. R.N.. 2010. Valor nutritivo do farelo de pinhão manso (Jatropha curcas) para alevinos de tilápia do Nilo (Oreochromis niloticus). Dissertação (Mestrado em Aqüicultura) - Centro de Aqüicultura - Universidade Estadual Paulista. Jaboticabal. SP. 81p. 